\title{
KIMBERLY ZARECOR, VLADIMIR KULIĆ THE PRESIDENT OF OUR COUNTRY IS A REAL ESTATE DEVELOPER
}

Kimberly Zarecor, Professor, lowa State University; 146 College of Design, 715 Bissell Rd., Ames, IA 50011; tel.: +1(515)294-5026

E-mail:zarecor@iastate.edu

Vladimir Kulić, Associate Professor, lowa State University; 146 College of Design, 715 Bissell Rd., Ames, IA 50011; tel.: +1(515)294-5676

E-mail:vkulic@iastate.edu

Interviewed by Nikolay Erofeev ${ }^{1}$

07.01.2019

\section{Abstract}

Professors of lowa State University and specialists in Socialist architecture and urban development, Kimberly Zarecor and Vladimir Kulić spoke in their interview about their approach to research and teach socialist architecture. They see the aim of their research in reintegrating the history of Eastern European and Soviet architecture into the general history of architecture. The main contribution of Soviet architects, they argue, was on developing typologies of public architecture, in contrast to the canonical Western architectural history, which celebrates private buildings. Soviet architects developed an entire culture of original, functional and economic public design. They see their course 'The Architectures of Global Socialism, taught at lowa State University, not only as an opportunity to learn from social legacies but also to start a broader discussion about socialism today.

Key words: socialist; architecture; urban; development; aesthetics; global socialism; teaching Citation: Zarecor K., Kulić V. (2018) The President of Our Country is a Real Estate Developer. Urban Studies and Practices, vol. 3, no 4, pp. 12-17.

DOI: https://doi.org/10.17323/usp34201812-17

Nikolay Erofeev (NE): You have started teaching the course 'The Architectures of Global Socialism' at Iowa State University (USA) this term. Could you tell us about the course? Why is it important to teach this course in the USA? Who is this course aimed at? Are American students interested in socialist architecture and urbanism, and if so, what specifically interests them?

Vladimir Kulić (VK): We are teaching a course on the history of global socialism. We are trying to approach it broadly, in both geographical and chronological terms. The first part of the course deals with the 19th century and the origins of socialism and the early architectural manifestations associated with it. We start with the unfavorable architectural situation of the 19th century and the horrible housing conditions during the industrial revolution, which are the reasons for the existence of socialism. This serves as an entry point. From the middle of the first semester, we approach the time of the so-called really-existing socialism: the Soviet revolution and Stalinist industrialization. But most of the course is dedicated to the post-World War II period, the expansion of socialism towards Eastern Europe and, from the late-1950s, its global expansion to the developing world. Finally, we're trying to reach pretty much the end of the Socialist period, the 1980s. This general framework gives a

1 Nikolay Erofeev, DPhil candidate, Faculty of History, University of Oxford, United Kingdom;

E-mail: nikolay.erofeev@oriel.ox.ac.uk 
relatively broad overview but the students can pick their own projects and dig deeper to explore more specific topics. We propose more specific themes for students to look at, such as mass housing, which is a very important theme throughout the Soviet period, we also look at socialist consumerism in the 1960s and the specifics of Socialist 'postmodernism' [Kulić, 2019]. We also propose some specific methodological approaches to the study of architecture and urbanism, such as the construction of memory.

Kimberly Zarecor (KZ): The important aspect of teaching this course is that so much new work has been done on Soviet architecture and urbanism recently. A lot of the books have appeared in the last ten years. There are scholars studying 'socialist architecture' in pretty much every postsocialist country nowadays. The body of research is so large that even we were struggling to decide what to assign for the main reading list and unfortunately, we won't have time to look deeply at the development in any of specific socialist countries. Ten years ago the situation was different, there were few publications about socialism. For us, this is a celebration, because we were among the first people to start this kind of research - this field of study was established by a small group including Vladimir and me. And now there's just an unbelievable amount of research being produced. This material gives us an opportunity to look at socialism in different geographic and national contexts in our course.

We're trying to think about our course not only as kind of a sweep through the historical part of socialism, but also to think through case studies in different contexts. Our students are contributing to the study of case-studies from different countries, and we can discuss how the architecture of Socialist Yugoslavia was different from Czechoslovakia, or from Vietnam. These national stories allow us to see this research through the eyes of our students, who are coming to the topic with no real background. Regarding the technical details: this is a course for both undergraduate and postgraduate students that they take as part of their master degree curriculum. We have 25 students doing our course this year and they are all studying to be architects in our professional Master of Architecture program at Iowa State. Half of the group are American students, the other half are international, from Korea, India, Iran, Venezuela, and China.

NE: A course on socialist architecture is something you would not normally expect to see in the architectural curriculum of US schools. Why is it important to teach and talk about socialist architecture in the US? Is it really that relevant to study the heritage of a country which no longer exists and a failed social and political alliance? You mentioned that many publications about socialist architecture have come out recently. Is this field becoming mainstream in general architectural history or is it still a marginal theme in academia?

VK: As scholars, we have to reintegrate the history of socialism into the general history of architecture, from which it has been excluded for a very long time. It used to be very difficult. In my previous school, I never had a chance to teach anything even close to this course or to my field of expertise and even today it is, in general, very often the case in most institutes. When we look at all of the major surveys of architectural history that are proposed, that are used to teach architectural history - not just in the US but worldwide - the socialist world is practically non-existent. But in a huge part of the world, it was a really important topic in 20th-century architecture. So we're already using this opportunity as a way of reintegrating that knowledge into the curriculum.

KZ: The theme is definitely still marginal. I've been working here for 13 and a half years and, because of Vladimir's arrival and other events, this is the first time I've had the chance to teach this topic. Suddenly we find out that there are many students here in the United States, especially college students, that are very interested in socialism, even if they don't know much about it. We don't expect our students to have a strong background in the history of socialism. But we think that this the right moment for a conversation about it. Also, these past ten years, especially after the economic recession and this rise of the far right across the world including this country, have posed important political questions about the socialist heritage. The destruction which has been brought by capitalism is well known. And we want to say, ok, capitalism is on the move and destroying certain aspects of the built environment and rebuilding them in a particular way. But how was the view of the socialist world different, what were the patterns, the modes of production of urban spaces? What 
were the perspectives of the architects who were working in socialist countries, and what can they teach us? Regardless of our opinion about socialist regimes and their politics, they invested huge efforts to make changes in the built environment. And there are many things which we can learn from these socialist legacies.

We want our students to feel that this is not just a historical topic, but a topic which is very relevant today. We are not likely to ever have a true left in the United States. It's impossible. None of the current movements on the left have any broad political power. Not in my opinion. Some students are interested in Bernie Sanders, the political candidate, and then Jeremy Corbyn in the UK context. Bernie Sanders' policies are never going to penetrate deeply into the government. We hear people say that they're democratic socialists, or that they're anti-capitalist - this is popular among the younger generation of students - they're trying to push against this particular neoliberal moment, but they don't know anything about socialism. We are interested in both educating our students about socialism and making them more sophisticated thinkers about socialism, and about what socialism could be. So we are trying to enter into this very urgent contemporary conversation using architecture, mass housing and the concept of the socialist good life as a way to talk about the difficult things that are happening right now with Putin, with Trump and with Corbyn.

We are now suddenly living in the worst possible capitalist excess of the real estate development industry. Even the president of our country is a real estate developer. If you think about Marx and Engels (our students read Engels), you see that in the 1870s, they are already talking about the property market and the real estate industry, saying they are of one of the basic evils of capitalism. And we are now at a moment in which it's come full circle, we have this person in charge of the country who's made his money through completely corrupt schemes and what's becoming known to be a kind of fraudulent business venture based on property values. Similarly, Moscow now is in the midst of an even more gigantic collapse of public housing. Authorities in your country also understood the public value of the built environment and how much money is in these buildings. In redeveloping socialist public spaces, they're about to privatize a huge amount of wealth.

NE: What makes the history of socialist architecture and the urban environment so specific in contrast to the architecture of the Western world? Do you emphasize the diversity of socialist countries or the similarities of the socialist past? Soviet architecture and planning is often seen as centralized, hierarchical, normalized and bureaucratic, is it so from your perspective?

VK: My position as someone working in Yugoslavia probably gives me a different perspective, so I've always been a proponent of the argument that it's very difficult to generalize about what socialist architecture is - there's a great deal of variety in all kinds of terms. But one of the arguments that we're trying to make is that architecture is a lot more than aesthetics. What makes the architecture of socialism fundamentally different are the modes of architectural production and the management of resources. Apart from that, in terms of architectural aesthetics or construction methods or any number of more specifically architectural factors, I don't think that there could be a common denominator that would apply in all socialist countries. I would rather emphasize the diversity and variety of the manifestations of socialist architecture. That is not to say that there was no common ground. For example, standardized building types were common. The standardized prefabricated mass housing is an obvious example of this common ground in a large part of the socialist world. But even if these standardized buildings look similar, a deeper analysis of the plans and standards reveals that they actually end up being quite different. So I do believe in specificity. For example, in the Yugoslav context, the story was completely different. Yugoslavia was never able to standardize its production partly because of its rather decentralized system, it never had one or a couple of prefabricated systems, there was a huge number of different systems that were in use and often combined with conventional methods. The design of apartments, apartment plans, was something that was very much a topic of experimentation in the 1970s and 1980s. Soviet housing abroad also shows great variety, if we look at Cuba or Chile (on Chile and Cuba, see [Alonso, Palmarola, 2013; 2014]).

KZ: My interest has to do with the socialist system more broadly, and understanding that the variations in form, the aesthetic differences, the differences in layouts of the apartments, or even the differences in the system of prefabrication or traditional construction - that underneath all of that there is this incredible project of transformation. Socialist projects were social, economic, 
political transformations - projects to build different kinds of lives, lifestyles, communities, in some cases in a kind of sinister or evil ways, but in other contexts, it took much more optimistic forms. That is what underlies the system. We shouldn't get too caught up in the actual object making but there's something just completely different about the way that housing and neighborhoods and cities function in socialist systems, at least in the most conceptual way and that the city - I write about this in my article - that a city is a kind of mechanism for production, it's an instrument [Zarecor, 2017].

VK: Socialist standardized buildings were a representation of public architecture. If we look at the canonical Western architectural history, it celebrates private buildings rather than public. Architectural history said the capitalist world was based on the bourgeois villa as the prototype. If you think of Fallingwater, Villa Savoye, the Vanna Venturi House - they are all pristine privatelyowned bourgeois villas. That's not the case anywhere in the socialist world. Even if a great part of the housing production was actually individual (e.g. vernacular architecture constituted $60 \%$ of the housing in Hungary), the individual was never the major concern of architects. Rather, socialist architects were interested in public urban spaces. These were objects of constant experimentation. And that's perhaps the biggest difference. And I think we agree about that, and this is one reason why the story of public housing in Moscow, for example, is so important. Now we see that public legacy being privatized, it's the stealing of this public legacy in every sense. An example of the contribution of socialism is now being taken away and privatized, and I don't think anyone wanted what's happening except for the people who are making the money.

NE: How was architectural production framed in a bureaucratic environment of norms and standards? It seems, there is no general vision about these norms at the moment. One view is that these norms gave architects effective tools for implementing the welfare project and delivering housing in the regions. However, Mark B. Smith, for example, in his book Property of Communists has a very conservative view that this kind of regionally standardized and normalized architectural production doesn't leave any space for architects [Smith, 2010].

VK: Khrushchevkas ${ }^{2}$ are the best representation of these norms. Steve Harris shows how bureaucratic rules determined the plans of apartments, which later became common in various part of the Socialist world [Harris, 2013, ch. 1]. This is a story of how closely bureaucratic regulations can actually determine the design. But honestly, I have not lived in better-designed apartments, perhaps with the exception of Marcel Breuer housing in Princeton, which in some ways is similar. There is this really incredible combination of very rigorous functionalism, there's absolutely no wasted space for anything, and kind of a version of a free plan, unlike most of the large-scale prefabricated buildings, we're talking here about skeletal structures that allow for flexibility of plans and a great deal of effort from the designer blended to generate a sense of openness and a sense that the apartment is much larger than it actually is. We're talking about relatively small standards, not quite 'existence minimum' - a little bit beyond that - but nowhere close to Western European standards.

Soviet architects developed the entire culture of how to design a good functional and economic apartment plan that's also going to be an architecturally valuable space. And that is also something that, in a way, needs to be taught to students nowadays. People still tend to dismiss Socialist urbanism as a uniform desert of concrete. However, the current housing and public building production is totally commercialized, apartment design is led merely by the d eveloper's requirements. It seems, that the architectural skill of designing good functional apartments has been completely lost.

\section{Notes:}

Vladimir Kulić and Kimberly Zarecor are interested to work with students pursuing master's level research on the history of socialist architecture. Iowa State University offers a one-year M.S. in Architecture degree with a program of study set up individually for each student. The Architecture of Global Socialisms seminar is offered each spring semester (January-May). Some funding may be available for qualified students. Students with funded fellowships such as Fulbrights are especially encouraged to consider Iowa State as a choice for their time in the United States. Scholars can also

2 Colloquial for the typical five-story Khrushchev-era apartment. 
come on short-term visit as invited researchers. Iowa State University can process a visa request for a visiting student or faculty researcher even if the university is not providing the funding for the visit. Please contact Vladimir Kulić (vkulic@iastate.edu) and Kimberly Zarecor (zarecor@iastate. edu) for more information.

\section{References}

Alonso P., Palmarola H. (2013) A Panel's Tale: The Soviet I-464 System and the Politics of Assemblage. Latin American Modern Architectures. New York and London: Routledge, pp. 153-169.

Alonso P., Palmarola H. (2014) Tropical Assemblage: The Soviet Large Panel in Cuba. Beyond Imported Magic: Essays on Science, Technology, and Society in Latin America (M. Eden, I. da Costa Marques, C. Holmes (eds)). Cambridge, Massachusetts: The MIT Press, pp. 159-179.

Harris S.E. (2013) Communism on Tomorrow Street: Mass Housing and Everyday Life after Stalin. Woodrow Wilson Center Press.

Kulić V. (2019) Second World Postmodernisms: Architecture and Society under Late Socialism. London: Bloomsbury Visual Arts.

Smith M.B. (2010) Property of Communists. DeKalb: Northern Illinois Univ. Press.

Zarecor K.E. (2017) What Was So Socialist About the Socialist City? Second World Urbanity in Europe.Journal of Urban History, vol. 44, no 1, pp. 95-117. Available at: https://doi.org/10.1177/0096144217710229 (accessed 7 January 2019). 


\title{
К. ЗАРЕКОР, В.КУЛИЧ \\ ПРЕЗИДЕНТ НАШЕЙ СТРАНЫ - ЗАСТРОЙЩИК
}

\author{
Зарекор Кимберли, профессор Государственного университета Айовы; 146 College of Design, \\ 715 Bissell Rd., Ames, IA 50011; тел. +1(515)294-5026 \\ E-mail: zarecor@iastate.edu \\ Кулич Владимир, доцент Государственного университета Айовы; 146 College of Design, \\ 715 Bissell Rd., Ames, IA 50011; тел. +1(515)294-5676 \\ E-mail:vkulic@iastate.edu \\ Интервьюер: Николай Ерофеев ${ }^{1}$ \\ Интервью состоялось 7 января 2019 г. \\ Профессор Университета штата Айова Кимберли Зарекор и специалист по социалистической \\ архитектуре и градостроительству Владимир Кулич рассказали в интервью о своем \\ подходе к исследованиям социалистической архитектуры и ее преподаванию. Целью \\ своих исследований они видят реинтеграцию истории восточноевропейской и советской \\ архитектуры в общую историю архитектуры. Зарекор и Кулич утверждают, что основной \\ вклад советских архитекторов заключался в разработке типологий общественной \\ архитектуры, в отличие от канонической истории развития западной архитектуры, в которой \\ прославляются частные здания. Советские архитекторы разработали целую культуру \\ оригинального, функционального и экономичного общественного дизайна. Зарекор и Кулич \\ рассматривают свой курс «Архитектура глобального социализма», который преподают \\ в Университете штата Айова, не только как возможность извлечь уроки из социалистического \\ наследия, но и начать более широкую дискуссию о социализме сегодня. \\ Ключевые слова: социалистический; архитектура; урбанистика; развитие; эстетика; \\ глобальный социализм \\ Цитирование: Zarecor K., Kulić V. (2018) The President of Our Country is a Real \\ Estate Developer // Городские исследования и практики. Т. 3. №4. С. 12-17. \\ DOI: https://doi.org/10.17323/usp34201812-17
}

\section{Источники}

Alonso P., Palmarola H. (2013) A Panel's Tale: The Soviet I-464 System and the Politics of Assemblage // Latin American Modern Architectures. N. Y.; L.: Routledge. P. 153-169.

Alonso P., Palmarola H. (2014) Tropical Assemblage: The Soviet Large Panel in Cuba // Beyond Imported Magic: Essays on Science, Technology, and Society in Latin America / M. Eden, I. da Costa Marques, C. Holmes (eds). Cambridge, Massachusetts: The MIT Press. P. 159-179.

Harris S.E. (2013) Communism on Tomorrow Street: Mass Housing and Everyday Life after Stalin. Woodrow Wilson Center Press.

Kulić V. (2019) Second World Postmodernisms: Architecture and Society under Late Socialism. L.: Bloomsbury Visual Arts.

Smith M.B. (2010) Property of Communists. DeKalb: Northern Illinois University Press.

Zarecor K.E. (2017) What Was So Socialist About the Socialist City? Second World Urbanity in Europe // Journal of Urban History. Vol. 44. No. 1. Р. 95-117. Режим доступа: https://doi.org/10.1177/0096144217710229 (дата обращения: 07.01.2019).

1 Ерофеев Н.А., докторант исторического факультета Оксфордского университета (Великобритания); E-mail: nikolay.erofeev@oriel.ox.ac.uk 